\title{
In Memory of Marcia McAdory Rachel, PhD, RN
}

A nurse, leader, educator, wife, mother, grandmother, and friend, Marcia McAdory Rachel, PhD, RN, passed away on September 26, 2020. A former president of the National Council of State Boards of Nursing (NCSBN) from 1994 to 1996, Marcia devoted her life to leadership, service, and excellence in nursing. Those who worked with her on the NCSBN Board of Directors remember her as an individual who used her many talents to serve others. No matter how stressful the situation, Marcia consistently exercised grace and strength. With her warm smile and contagious laughter, she considered everyone she met to be a friend.

Marcia's nursing career began when she received her bachelor of science in nursing degree from Mississippi College. She went on to earn a master's degree in mental health nursing and a doctorate in higher education and student personnel, both from The University of Mississippi. Marcia served as a mental health and home health nurse, but she was compelled to branch out into nursing administration and teaching. She served as the executive director of the Mississippi Board of Nursing, a chief nursing executive at the University of Mississippi Medical Center Hospitals and Clinics, a nurse educator at the graduate and undergraduate levels, and, most recently, the associate dean for academic affairs at the University of Mississippi Medical Center School of Nursing.

Throughout her career, Marcia was a mentor to countless nursing professionals and a leader of many educational initiatives. In addition to serving as NCSBN's president, Marcia was president of the Commission on Graduates of Foreign Nursing Schools. She devoted 13 consecutive years serving the Mississippi Nurses Foundation and led the scholarship committee with structure and a true desire to support students.

Marcia also served on the Nightingale Committee for the Mississippi Nurses Foundation and was a member of the Mississippi Organization of Nurse Executives, the Mississippi Nurses Association, Sigma Theta Tau, and the American Nurses Association. She was inducted into the Mississippi Nurses
Association Hall of Fame. Other honors include induction into Sigma Theta Tau, Phi Kappa Phi, and Kappa Delta Pi, and she was a recipient of the $\mathrm{R}$. Louise McManus award from NCSBN.

Marcia consulted with orga-

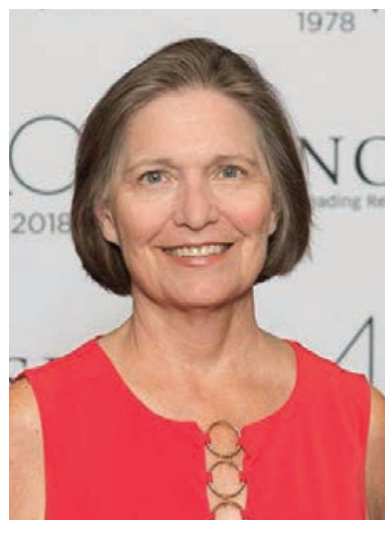
nizations regarding evidence-based practice; strategic planning; and leadership, management, and regulatory issues in nursing. She was certified as an advanced nurse executive through the American Nurses Credentialing Center and served as an appraiser for the center's Magnet Recognition Program. Her publications and presentations were primarily related to leadership issues, quality improvement, and internationally educated nurses, and she served as a peer reviewer and sentinel reviewer/rater of articles for several entities.

In her personal life, Marcia married Steven John Rachel on November 20, 1976. They had two children, Christopher Steven Rachel and Rebecca Rachel Holt, and four grandchildren. Marcia gave back to her community, volunteering with her church as a congregational health nurse. She had a unique gift for knowing when to offer advice or a listening ear, whether in her personal or professional life, and she managed to intertwine her quick wit and humor into conversations whenever possible.

Marcia believed in NCSBN's mission, which is rooted in public protection, and worked diligently to strengthen the role of nursing regulatory bodies in nursing regulation. Summing this dedication up in her own words, "Indeed, tomorrow the boards of nursing promise to be full of opportunities, and I have no doubt that together, we will face challenges before us with the same determination and dedication to quality that has been our hallmark since the National Council's inception." Marcia embodied this outlook, and the nursing profession has no doubt benefited from her tireless, lifelong commitment to nursing. 